УДК $81 ’ 37$

БИНАРНАЯ ОППОЗИЦИЯ «ПЕЧАЛЬ-РАДОСТЬ» В РУССКОМ И АНГЛИЙСКОМ ЯЗЫКАХ

Таджибова 3.T., к.ф.н.,

Дагестанский государственный университет народного хозяйства,

\title{
BINARY OPPOSITION "SADNESS-JOY" IN RUSSIAN AND ENGLISH LANGUAGES
}

\author{
Tadzhibova Z.T., \\ Ph.D., \\ Dagestan State University of National Economy
}

\begin{abstract}
Аннотация. Статья посвящена компаративному исследованию бинарной оппозиции концептов «печальрадость» в идиоматической картине мира разносистемных языков. Автор выделяет такие тематические группы реализации данных концептов, как «шутить», «радоваться», «печалиться», «быть счастливым», «быть грустным, печальным». В ходе исследования, обнаружено совпадение в лингвокультурах по отношению к данным концептам, когда подчеркивается связь печали и радости, призывается терпеть тяжелые моменты жизни и не отчаиваться, рекомендуется не делать поспешные выводы. В отдельную группу можно объединить пословицы, раскрывающие отношение русских и англичан к счастью. Исходя из полученного материала, можно выделить несколько принципов, выражающих отношение к счастью. Во-первых, счастье никто не выбирает, и оно в данном случае понимается как «удача, везенье» и дается свыше. Во-вторых, счастье в противовес первой группе пословиц, воспринимается как категория, которую надо добиваться/ заработать/ заслужить. В-третьих, были обнаружены пословицы, в которых счастье важная часть жизни глупых людей и чаще всего им достается. Автор приходит к выводу, что данные концепты являются универсальными во всех исследуемых лингвокультурах, но их реализация, отраженная в плоскости паремиологической картины мира, носит специфичный характер.

Annotation. The article is devoted to a comparative study of the binary opposition of the concepts "sadness-joy" in the idiomatic picture of the world of multi-system languages. The author identifies such thematic groups for the implementation of these concepts as "joke", "rejoice", "grieve", "be happy", "be sad, sadness". In the course of the study, a coincidence was found in linguistic cultures in relation to these concepts, when the connection between sadness and joy is emphasized, it is called upon to endure difficult moments of life and not to despair, it is recommended not to make hasty conclusions. A separate group can be combined with proverbs that reveal the attitude of Russians and British to happiness. Based on the material received, several principles can be distinguished that express the attitude towards happiness. First, no one chooses happiness, and in this case, it is understood as "luck, luck" and is given from above. Secondly, happiness, as opposed to the first group of proverbs, is perceived as a category that must be achieved / earned / deserved. Thirdly, proverbs were discovered in which happiness is an important part of the life of stupid people and most often they get it. The author comes to the conclusion that these concepts are universal in all the studied linguocultures, but their implementation, reflected in the plane of the paremiological picture of the world, is specific.
\end{abstract}

Ключевые слова: концепт, лингвокультурология, сопоставительный анализ, пословицы и поговорки.

Key words: concept, cultural linguistics, comparative analysis, proverbs and sayings.

Концепты «печаль», «радость» относятся к эмоциональным концептам, в которые несмотря на противоположное значение имеет много общего в структурной и вербальной реализации. Исследование этих концептов с точки зрения бинарной оппозиции помогает глубже понять и раскрыть сущность этих понятий. Эмоциональные концепты образуют эмоциональную картину мира того или иного языка, что в свою очередь в отличие от языковой картины мира имеет дополнительные вкрапления в виде эмотивных, оценочных, стилистически-окрашенных коннотативных значений. Сопоставительное исследование концептов «печальрадость» в паремиологии разноструктурных языков позволяет раскрыть как общие, универсальные понятия, так и национально-специфичные.

При сравнительно-сопоставительном исследовании бинарной оппозиция «печаль-радость» возможно выделение нескольких сфер реализации данных концептов:

Во-первых, данная оппозиция ярко представлена в паремиях со значением «шутить». Например, «Шутить над другим - любить шутку над собой» в русском языке и «If you give a jest, you must take a jest» (букв. «Если сам шутишь, то умей шутку и принять»).

В русском языке встречаются топонимические аспекты, отражающие реалии русского народа и народные имена. Например, «Шутил Мартын, да и свалился под тын». Этой пословице соответствует английская «He laughs ill that laughs himself to death» (букв. «Кто от смеха умирает, тот плохо смеется»). Эти пословицы указывают на 
то, что во всем хорошо соблюдать меру, даже в радостях и шутках. При этом, если в русском языке используется личное имя (Мартын), то английская конструкция предложения предполагает использование местоимения, и тем самым безличное обращение.

Также пословица «Ранний смех - поздние слезы» и ее соответствие в английском «Laugh before breakfast, you'll cry before supper» (букв. «Посмеешься перед завтраком - будешь плакать перед ужином») предостерегают от поспешных действий. Возможен и другой близкий вариант в английском языке «Sing before breakfast, cry before night» (букв. «Петь перед завтраком - плакать перед наступлением ночи»). Как видим в английском языке присутствуют дополнительные антонимичные пары «breakfast - supper» (завтрак-ужин), «breakfast - night» (завтрак-ночь), что подчеркивает скрупулезный и педантичный характер англичан.

Во-вторых, в исследуемых лингвокультурах подчеркивается связь и неразрывность печали и радости, как естественных состояний человеческого бытия. В русском языке так и говорят - «Нет радости без печали», что соответствует английской пословице «No јoy without alloy». Также в примере «Горе по соседству с радостью ходит» в русском языке и «Sadness and gladness succeed each other»» (букв. «Печаль и радость сменяют друг друга») признается факт связи этих двух концептов. Русские пословицы «Где радость, тут и горе; где горе, там и радость», «За весельем горесть ходит по пятам» соответствуют английской «After joy comes sorrow» (букв. «После радости приходит печаль»). Английская пословица «Every day has its nights, every weal its woe» (букв. «У всякого дня есть своя ночь, а у всякой радости - своя печаль»). То есть в русской и английской культурах признается взаимосвязь радости и печали, что находит отражение в пословицах и поговорках этих народов.

Рассматривая концепт «печаль, горе» возможно наличие общих пониманий в плане отношения к этому концепту. В обоих лингвокультурах используется призыв к терпению и смирению. Например, в русском языке «С бедой не перекоряйся, терпи» и в английском - «What can’t be cured must be endured» (букв. «Что нельзя вылечить, то нужно вытерпеть»).

Русские и англичане одинаково относятся к печали и видят единственный выход в терпении. Так русской пословице «Терпение приносит спасение» соответствуют английские «Рatience is the plaster for all sores» (букв. «Терпение - пластырь от всех ран»), «Рatience is remedy for every grief» (букв. «Терпение - лекарство от любой печали»). В сознании англичан терпение воспринимается как лечебное составляющие необходимое в тяжелой ситуации.

Также в обоих лингвокультурах совпадает мнение, что нельзя отчаиваться и придаваться унынию. Например, в русском - «Слезами горю не поможешь». Следует помнить, что горе/печаль временное явление. Например, «Худое видели, хорошее увидим» - «Тhe worse luck now, the better another time» (букв. «Не повезло сейчас, повезет в другой раз»). Народная мудрость призывает нас находить что-то хорошее в любом положении, каким бы плохим оно нам не казалось. Например, «Во всяком худе не без добра» - «Nothing so bad in which there is not something of good» (букв. «Ничего не бывает настолько плохим, чтобы в нем не было бы чего-нибудь хорошего»). Если ничего не можешь сделать, то не стоит грустить и думать об этом, что подтверждают пословицы «Перестань тужить, чему нельзя пособить» - в русском языке и «Never grieve for what you cannot help» (досл. «Никогда не грусти о том, чему ты не можешь помочь»); «Past cure, past care» (досл. «Слишком поздно лечить, слишком поздно и беспокоиться»); «It is too late to grieve when the chance is past» (досл. «Слишком поздно горевать, когда возможность упущена»).

В английской лингвокультуре концепты «печаль-радость» часто сравниваются с природными явлениями. Например, «After storm comes a calm» (досл. «После бури наступает затишье»); «After black clouds clear weather» (досл. «После черных облаков - хорошая погода»); «After rain comes sunshine» (досл. «После дождя светит солнце»). Большое количество «погодных» паремий можно объяснить переменчивым климатом на британских островах. В русской культуре радость ассоциируется с ясным днем и красным (в раннем представлении красный - красивый) солнцем - «Не все ненастье, проглянет и красное солнышко». Также употребление уменьшительноласкательного слова «солнышко» создает успокоительный эффект.

Часто проблемы и беды наслаиваются друг на друга, в этом случае говорят: «Одна беда идет, другую ведет», «Пришла беда - отворяй ворота» в русском языке и «Misfortunes never come singly» (досл. «несчастья никогда не приходят по одиночке»); «It never rains, but it pours» (досл. «Если идет дождь, то всегда ливнем»); «Of one ill, соте many» (досл. «Из одной беды выходит много»); «Ill comes often on the back of worse» (досл. «Плохое часто приходит на спине худшего»).

Как видим, с одной стороны - не следует отчаиваться, после плохого придет хорошее, а с другой стороны беды несут еще большие беды, проблемы.

Также пословицы предостерегают от поспешных выводов. Например, «Не реви раньше смерти» - «Don’t cry before you are hurt» (досл. «Не кричи, пока тебе не больно»), также русская пословица «Хвали жизнь при смерти, а день вечером» и ее английский эквивалент «Praise day at night, and life at the end».

Воздействие печали и радости на внешность подмечена ив русской и в английской культуре. Например, «Печаль не красит, горе не цветит» - «Adversity flatters no man» (досл. «Горе никого не красит»); «Сердце веселится и лицо цветет» - «A blithe heart makes a blooming visage» (досл. «От счастливого сердца - цветущее лицо»). 
Русские пословицы «На людях и горе в полгоря», «Вместе потужим - в полгоря» соответствуют английским «Two in distress make sorrow less» (досл. «Горевать вдвоем - печаль меньше»); «Misery loves company» (букв. «Горе любит компанию»); «A trouble shared is a trouble halved» (досл. «Разделённое горе - это горе, поделённое пополам»); «Grief is lessened when imparted to others» (досл. «Горе уменьшается, если его разделить с другими»); «It is good to have company in trouble» (досл. «Хорошо иметь в беде компанию») показывают, что и русские и англичане считают, что вместе преодолеть трудности намного легче, чем одному.

Также русская пословица «С доброй женой горе - полгоря, а радость вдвойне» говорит о том, что любому человеку необходима поддержка близкого. Английское соответствие «Marriage halves our griefs, doubles our joys and quadruples our expenses» (досл. «Супружество делит пополан наше горе, удваивает наши радости и учетверяет наши расходы») отражает практичный характер британцев и расширяет представление о супружеских отношениях.

В русской лингвокультуре пройдя через трудности человек узнает жизнь, поэтому в народе говорят: «Натерпишься горя - научишься жить», что соответствует английским «Adversity makes a man wise, though not rich» (досл. «Несчастья делают человека мудрым, хотя и не богатым»); «Trouble brings experience and experience brings wisdom» (досл. «Беда дает опят, а опыт дает мудрость»). В данном случае английские пословицы носят более конкретный характер и акцентируются на постижении мудрости.

Также были обнаружены пословицы, которые оценивают степень горя и в своей внутренней форме содержат олицетворение. Например, «Легкое горе болтливо, тяжелое - безмолвно» - «Small sorrows speak; great ones are silent» (досл. «Маленькое горе говорит, большое - молчит»).

Только испытав трудности и проблемы, человек будет ценить хорошее, например, в русском «Не видав горя, не узнаешь и радости», «Не вкусив горького, не узнаешь и сладкого» и в английском «No man better knows what good is than he who has endured evil» (досл. «Никто лучше не знает, что такое добро, чем тот, кто испытал зло»); «He deserves not the sweet that will not taste the sour» (досл. Кто не пробовал горького, не достоин сладкого»).

В пословицах исследуемых языков даются советы по отношению поведения доброго или злого и его последствий, причем в английском языке обнаружено больше примеров чем в русском - «Сделав худо, не жди добра» - «Не that does evil, never weens good» (букв. «Кто творит зло, тот никогда ничего хорошего не ждет»); «Не that mischief hatches, mischief catches» (букв. «Кто зло замышляет, тот зло и получает»); «Curses, like chickens, come home to roost» (букв. «Проклятия, как цыплята, приходят домой на насест»).

Библейское высказывание «Поступай по отношению к другим так, как ты бы хотел, чтобы поступали по отношению к тебе» нашло отражение и в русском - «Когда хочешь себе добра, то никому не делай зла» и в английском языках - «Do as you would be done by» (букв. «Делай так, как делалось бы тебе»); Do well and have well (букв. «Делай добро и получишь добро»).

В отдельную группу можно объединить пословицы, раскрывающие отношение русских и англичан к счастью. Исходя из полученного материала, можно выделить несколько принципов, выражающих отношение к счастью.

Во-первых, счастье никто не выбирает, и оно в данном случае понимается как «удача, везенье» и дается свыше. Например, в русском языке - «У кого счастье поведется, у того и петух несется» и в английском - «Whom God loves, his bitch brings forth pigs» (букв. «Кого бог любить, у того и собака родит свиней»). В обоих пословицах понимание счастья отражает бытовую сферу жизни и связаны с ведением сельского хозяйства. Также пример «Хорошо плясать тому, кому счастье подсвистывает» в русском языке и «He dances well to whom fortune pipes» в английском. Также подтверждение тезиса о счастье-удаче можно проследить в следующих пословицах: «Со счастьем хорошо и по грибы ходить» - характерный для русского народа уклад жизни, бескрайние лесные просторы и поход за грибами как привычное занятие. Что касается английского соответствия, то поговорка «Give a man luck and throw him into the sea» (букв. «Дай человеку удачу и брось его в море») отражает географическое положение, со всех сторон окружённая морем Британия по особому относится к морю, поэтому если счастьеудача сопутствуют человеку, то и в открытом море он не пропадает.

Во-вторых, счастье в противовес первой группе пословиц, воспринимается как категория, которую надо добиваться/ заработать/ заслужить. Например, в русском языке - «Счастье не в воздухе вьется, а руками достается» и в английском - «Good luck comes by cuffing» (букв. «Удача дается, если бить руками»).

B-третьих, были обнаружены пословицы, в которых счастье важная часть жизни глупых людей и чаще всего им достается. Например, в русском языке - «Счастье дураков любит, а несчастье и умного губит» и в английском - «Fortune favors fools» (букв. «Судьба покровительствует дуракам»); «Fools for luck» (букв. «Дураки на счастье»); «God sends fortune for fools» (букв. «Бог посылает дуракам удачу»). Также в обоих лингвокультурах положительное совпадает в пользу счастья нежели ума, мудрости. В русском языке - «Иногда горсточка счастья, лучше воза ума» и в английском языках - «An ounce of fortune is worth a pound of discretion» (букв. «Унция удачи стоит фунта благоразумия»).

Таким образом, при вербализации бинарной оппозиции «печаль-радость» можно прийти к следующим выводам:

онцепты «печаль-радость» относятся к категориям, выражающим эмоции и чувства человека; 
анные концепты являются универсальными во всех исследуемых лингвокультурах, но их реализация, отраженная в плоскости паремиологической картины мира, носит специфичный характер.

онцептуальный анализ одного понятия (радость или печаль) не полным без оппозиционной составляющей, поэтому в данной работе рассматривается бинарная оппозиция этих концептов.

В результате анализа концептов различных неродственных языков возможно более четкое представление языковой картины мира того или иного языка, ее эмоциональной составляющей, выделение репрезентантов базовых концептов в той или иной лингвокультуре.

В заключении, следует отметить, что концепты «печаль-радость» репрезентируют не только универсальные понятия, но также национально-специфичные. Эти смыслы обусловлены национальными, ментальными, историческими и социальными особенностями.

\section{Список использованной литературы:}

лефиренко Н.Ф. Лингвокультурология: ценностно-смысловое пространство языка. - М.: Флинта, 2010. - 288 с.

2. Вотякова И.А., Туктангулова Е.В. Репрезентация концептов «Радость» и «Печаль» в практике обучения русскому языку как иностранного. Вестник Удмуртского университета. Серия «История и филология». - Вып. 4, 2014. - С. 184-190.

ванова А.Г. 1000 русских и английских пословиц и поговорок: АСТ, Сова. 2010.

4. Озерова Е.Г., Покручина М.Ю. Концепт «радость» в лингвокультуре русского языка и его репрезентация в русских прозаических текстах. // Вопросы журналистики, педагогики, языкознания. Языкознание и литературоведение. - 2016.

\section{References:}

1. Alefirenko N.F. Lingvokul'turologiya: tsennostno-smyslovoye prostranstvo yazyka. - M.: Flinta, $2010 .-288$ s.

2. Votyakova I.A., Tuktangulova Ye.V. Reprezentatsiya kontseptov «Radost'» i «Pechal'»v praktike obucheniya russkomu yazyku kak inostrannogo. Vestnik Udmurtskogo universiteta. Seriya «Istoriya i filologiya». - Vyp. 4, 2014. S. 184-190.

3. Ivanova A.G. 1000 russkikh i angliyskikh poslovits i pogovorok: AST, Sova. 2010.

4. Ozerova Ye.G., Pokruchina M.YU. Kontsept «radost'» v lingvokul'ture russkogo yazyka i yego reprezentatsiya v russkikh prozaicheskikh tekstakh. // Voprosy zhurnalistiki, pedagogiki, yazykoznaniya. YAzykoznaniye i literaturovedeniye. -2016. 